Article

\title{
Addition of Carbonaceous Material to Aquatic Sediments for Sorption of Lindane and $p, p^{\prime}$-Dichlorodiphenyldichloroethylene
}

\author{
Zhiyong Guo ${ }^{1} \mathbb{D}$, Tianyi Chen ${ }^{1}$, Xinzhou Wang ${ }^{2}$, Liwen Zhang ${ }^{1}$, Liting Wang ${ }^{1}$, Deming Dong ${ }^{1}$ \\ and Xiuyi Hua ${ }^{1, *}$ \\ 1 Key Laboratory of Groundwater Resources and Environment, Ministry of Education, Jilin Provincial Key \\ Laboratory of Water Resources and Environment, College of New Energy and Environment, Jilin University, \\ Changchun 130012, China; zyguo@jlu.edu.cn (Z.G.); chenty18@mails.jlu.edu.cn (T.C.); \\ zhangliwen@jlu.edu.cn (L.Z.); wanglt17@mails.jlu.edu.cn (L.W.); dmdong@jlu.edu.cn (D.D.) \\ 2 Hebei Key Laboratory of Geological Resources and Environment Monitoring and Protection, Shijiazhuang \\ 050021, China; wangxinzhou76@126.com \\ * Correspondence: huaxy@jlu.edu.cn; Tel./Fax: +86-0431-85168429
}

Received: 22 March 2019; Accepted: 22 April 2019; Published: 26 April 2019

check for updates

\begin{abstract}
Isomers of hexachlorocyclohexanes ( $\mathrm{HCHs}$ ) and metabolites of dichlorodiphenyltrichloroethanes (DDTs) are still frequently detected worldwide in considerable amounts, even decades after their prohibition. Carbonaceous materials (CMs) have been shown to significantly reduce risks of propagation to humans by binding the hydrophobic organochlorine pesticides (OCPs) present in aquatic sediments. In the present study, black carbons extracted from natural sediments, and artificially produced black carbons, including black carbons by burning rice straw at 450 and $850{ }^{\circ} \mathrm{C}$, and a commercial activated carbon were compared to investigate the factors affecting the sorption of $\gamma-\mathrm{HCH}$ (lindane) and $p, p^{\prime}$-dichlorodiphenyldichloroethylene ( $p, p^{\prime}$-DDE) on CMs. The results indicated that when the proportion of CMs to total organic carbon $\left(f_{\mathrm{CM}} / f_{\mathrm{OC}}\right)$ was greater than 0.35 , CMs played a leading role in the sorption of lindane and $p, p^{\prime}-D D E$ by the sediments. The sorption contribution rate of CMs could reach up to $64.7 \%$. When the ratio of $f_{\mathrm{CM}} / f_{\mathrm{OC}}$ was less than 0.10 , CMs played a minor role in the sorption. In addition, the nonlinearity of the sorption isotherms was strengthened with the increasing the proportion of CMs to total organic carbon. Our findings show that $f_{\mathrm{CM}} / f_{\mathrm{OC}}$ value is a principal parameter for assessing the sorption capacity of sediments added by CMs for OCPs.
\end{abstract}

Keywords: organochlorine pesticide; hydrophobic organic compound; persistent organic pollutant; black carbon; activated carbon; rice straw

\section{Introduction}

Organochlorine pesticides (OCPs) are a class of persistent organic pollutants (POPs) used extensively from the 1940s through the 1960s in agriculture and mosquito control. Although they have been prohibited for over 40 years, they and their metabolites still persist, propagate in food chains and have adverse effects on aquatic organisms and human beings [1,2]. Hexachlorocyclohexanes (HCHs) and dichlorodiphenyltrichloroethanes (DDTs) are two classic OCPs that are frequently used as insecticides. Although they were banned in 1983 for agricultural use in China, they still pose a serious threat to human health and aquatic environment because of their historical use and reemissions [3-6]. Gamma-hexachlorocyclohexane $(\gamma-\mathrm{HCH})$, also well known as lindane, is one typical isomer of HCHs. It has already been a global environmental problem because of historical use and strong persistence [7]. 
$p, p^{\prime}$-dichlorodiphenyldichloroethylene ( $p, p^{\prime}$-DDE), one of the main metabolites of DDT, can exist for decades in soils and aquatic sediments and have adverse effects on humans and the environment [8-11].

Sorption is an important mechanism for the interaction between OCPs and natural solids in aquatic environments [12], and it is closely related to the physicochemical properties of solids. Sediment is one of the common natural solids in aquatic environment that can sorb OCPs. The sorption of OCPs by the sediments has already caused great concern because of its importance in the migration and transformation of OCPs [13-15]. Although many factors affect the distribution and sorption of OCPs, total organic matter content is one of the most important in this regard in the sediments [16].

Carbonaceous materials (CMs) are one of the main sources of total organic matter in aquatic sediments. Studies over the past two decades have shown that CMs have a key influence on the migration and transformation of organic pollutants in water $[17,18]$. Black carbon $(\mathrm{BC})$, usually defined as a CM formed during the incomplete combustion of biomass, is one of the CMs typically found in natural sediments [19]. The possible sources of BC in the sediments (SC) are the burning of nearby agricultural waste, vehicle exhaust emissions, and the burning of fossil fuel [1], which cause the BC to have a more complicated composition. Comparatively speaking, artificially prepared CMs, such as activated carbon (AC) and the BC produced by burning rice straw at 450 (BC450) and $850{ }^{\circ} \mathrm{C}(\mathrm{BC} 850)$ have relatively simple composition. The differences of physicochemical properties between the four $\mathrm{CMs}$ make their sorption characteristics more different. However, studies on the factors affecting the sorption of OCPs on CMs by comparing CMs in natural sediments with artificially prepared CMs are relatively scarce.

The aims of this study were to investigate the effects of CMs on the sorption of lindane and $p, p^{\prime}$-DDE by the sediments. Lindane and $p, p^{\prime}$-DDE were selected as model OCPs; BC450, BC850, AC, and $\mathrm{BC}$ extracted from sediments were selected as model CMs. The physicochemical properties of CMs can have important effects on the sorption of sediments, therefore, these four CMs were compared to select the most suitable and typical one to investigate the effect of CMs on the sorption of lindane and $p, p^{\prime}$-DDE by the sediments.

\section{Materials and Methods}

\subsection{Materials}

Surface sediments ( $5 \mathrm{~cm}$ in depth) were collected from the Songhua River in Northeastern China. A part of the sediments was freeze-dried and ground to pass through a $0.15 \mathrm{~mm}$ sieve for $\mathrm{BC}$ extraction. The extraction procedure of $\mathrm{BC}$ from sediments was referred by Lim et al. [20]. In brief, the procedure was as follows: (1) added $15 \mathrm{~mL}$ of $3 \mathrm{~mol} \cdot \mathrm{L}^{-1} \mathrm{HCl}$ to $3 \mathrm{~g}$ sediments, reacted for $24 \mathrm{~h}$ to remove carbonates; (2) added $20 \mathrm{~mL}$ of mixed solution of $10 \mathrm{~mol} \cdot \mathrm{L}^{-1} \mathrm{HF}$ and $1 \mathrm{~mol} \cdot \mathrm{L}^{-1} \mathrm{HCl}$, reacted for $12 \mathrm{~h}$ to remove silicates; (3) added $15 \mathrm{~mL}$ of $10 \mathrm{~mol} \cdot \mathrm{L}^{-1} \mathrm{HCl}$ and reacted for $24 \mathrm{~h}$ to remove $\mathrm{CaF}_{2}$; (4) added $20 \mathrm{~mL}$ of mixed solution of $0.1 \mathrm{~mol} \cdot \mathrm{L}^{-1} \mathrm{~K}_{2} \mathrm{Cr}_{2} \mathrm{O}_{7}$ and $2 \mathrm{~mol} \cdot \mathrm{L}^{-1} \mathrm{H}_{2} \mathrm{SO}_{4}$, reacted at $55^{\circ} \mathrm{C}$ for $60 \mathrm{~h}$ to remove the active organic carbon; (5) dried at $60^{\circ} \mathrm{C}$ in a drying oven to attain constant weight. The obtained residue comprised the $\mathrm{BC}$ samples, which was recorded as SC. The extracted samples were placed in a crucible and fired in a muffle furnace at $375^{\circ} \mathrm{C}$ for $4 \mathrm{~h}$. The $\mathrm{BC}$ contents recorded as $f_{\mathrm{CM}}$ were measured through determining the total organic carbon (TOC) contents of the residue.

Rice straws were collected from the riverine farmland of the Songhua River. The BC preparation from the rice straws was referred by Hsieh et al. [21]. The burning temperatures were 450 and $850{ }^{\circ} \mathrm{C}$, and the $\mathrm{BC}$ produced under the two temperatures were recorded as $\mathrm{BC} 450$ and $\mathrm{BC} 850$, respectively. AC was purchased from Guangfu Technology Co. Ltd. (Tianjin, China, 2010). Lindane (99\% purity) and $p, p^{\prime}$-DDE (98\% purity) were purchased from Dr. Ehrenstorfer GmbH (Augsburg, Germany, 2010). The basic physicochemical properties of lindane and $p, p^{\prime}$-DDE are listed in Table 1. Methanol was used in the preparation of standards of lindane and $p, p^{\prime}$-DDE. All of the other reagents and chemicals used were of analytical grade and purchased from Sinopharm Chemical Reagent Co., Ltd., Shanghai, China, 
2010. The water used in the experiment was Milli-Q water. Chromosulfuric acid was used to clean the laboratory glassware.

The specific surface area (SSA), pore size, and TOC contents of the sediments and the four CMs were characterized by SSA and pore size distribution analyzer (NOVA-2000E, Quantachrome Instruments, Boynton Beach, FL, USA, 2005), and TOC analyzer (TOC-VCPH, Shimadzu, Tokyo, Japan, 2006), respectively, as described in our previous studies [14,22]. The values of SSA were calculated using the BET multipoint method.

Table 1. The physicochemical properties of lindane and $p, p^{\prime}$-dichlorodiphenyldichloroethylene $\left(p, p^{\prime}-\mathrm{DDE}\right)$.

\begin{tabular}{|c|c|c|c|c|c|c|c|}
\hline $\begin{array}{l}\text { Organochlorine } \\
\text { Pesticide }\end{array}$ & $\begin{array}{c}\text { Structural } \\
\text { Formula }\end{array}$ & $\begin{array}{l}\text { Molecular } \\
\text { Formula }\end{array}$ & $\begin{array}{l}\text { Melting } \\
\text { Point }\left({ }^{\circ} \mathrm{C}\right)\end{array}$ & $\begin{array}{l}\text { Solubility } \\
\left(\mathrm{mg} \cdot \mathrm{L}^{-1}\right)\end{array}$ & $\begin{array}{l}\text { Vapor Pressure } \\
\text { (mmHg) }\end{array}$ & $\begin{array}{l}\text { Octanol-Water Partition } \\
\text { Coefficient (LogKow) }\end{array}$ & $\begin{array}{c}\text { Bioconcentration } \\
\text { Factor }\end{array}$ \\
\hline Lindane & & $\mathrm{C}_{6} \mathrm{H}_{6} \mathrm{Cl}_{6}$ & 112.5 & 7.30 & $\begin{array}{l}4.2 \times 10^{-5} \\
\left(20^{\circ} \mathrm{C}\right)\end{array}$ & 3.72 & $1.4 \times 10^{4}$ \\
\hline$p, p^{\prime}-\mathrm{DDE}$ & & $\mathrm{C}_{14} \mathrm{H}_{8} \mathrm{Cl}_{4}$ & 89.0 & 0.12 & $\begin{array}{c}6.0 \times 10^{-6} \\
\left(25^{\circ} \mathrm{C}\right)\end{array}$ & 6.51 & $9.8 \times 10^{5}$ \\
\hline
\end{tabular}

\subsection{Batch Sorption Experiments of Lindane and $p, p^{\prime}-D D E$ by the Sediments}

All sorption experiments were conducted in triplicate following a batch equilibration method at $25 \pm 1{ }^{\circ} \mathrm{C}$. Sorption of lindane and $p, p^{\prime}$-DDE, with the concentration levels ranging from 0.5 to $4.0 \mu \mathrm{g} \cdot \mathrm{L}^{-1}$, were conducted by mixing $10 \mathrm{mg}$ dry weight of the sediments in $250 \mathrm{~mL}$ stoppered conical flasks. These flasks were rotated continuously for $24 \mathrm{~h}$ at $120 \mathrm{r} \cdot \mathrm{min}^{-1}$ in a thermostatic oscillator. The pre-experiment indicated that the apparent equilibrium was reached within $24 \mathrm{~h}$. The initial $\mathrm{pH}$ value of the solution system was about 7.1. The contents of lindane and $p, p^{\prime}$-DDE in equilibrium sorption solution were determined by gas chromatography. The sorption amount of the two sorbates on the sediments was calculated by the subtraction method. Blank experiments containing sorbents without sorbates and containing sorbates without sorbents were carried out. Both the losses of lindane and $p, p^{\prime}$-DDE by degradation and volatilization, as well as the effects of dissolving matters from the solids on the determination results were negligible.

\subsection{Effects of CMs on the Sorption of Lindane and $p, p^{\prime}-D D E$}

Sorption of lindane and $p, p^{\prime}$-DDE, with the concentration levels ranging from 0.5 to $4.0 \mu \mathrm{g} \cdot \mathrm{L}^{-1}$, were conducted by mixing $10 \mathrm{mg}$ dry weight of separate SC, BC450, BC850, and AC in a group of $250 \mathrm{~mL}$ stoppered conical flasks. The effects of SC content on the sorption of lindane and $p, p^{\prime}$-DDE by the sediments were investigated in the same way as in the aforementioned sorption experiment in addition to the sorption systems added by $10 \mathrm{mg}$ sediments containing $0.5 \% \mathrm{SC}, 1.5 \% \mathrm{SC}, 3.0 \% \mathrm{SC}$, $5.0 \%$ SC, and $9.0 \%$ SC.

\subsection{Determination of Lindane and $p, p^{\prime}-D D E$}

The lindane and $p, p^{\prime}$-DDE in the equilibrium solution were extracted using C18 solid-phase extraction columns. Each column was sequentially conditioned with $6.0 \mathrm{~mL}$ of $\mathrm{n}$-hexane and $6.0 \mathrm{~mL}$ of methanol prior to use, and the water samples were loaded at a flow rate of $10 \mathrm{~mL} \cdot \mathrm{min}^{-1}$. After drying, the columns were eluted with $6 \mathrm{~mL}$ of $\mathrm{n}$-hexane. The extract was concentrated to $1 \mathrm{~mL}$ by nitrogen blowing. Their determination was performed using a gas chromatograph equipped with an electron capture detector (GC-ECD, GC-14C, Shimadzu, Tokyo, Japan, 2006). The carrier gas was high-purity nitrogen $\left(99.999 \%\right.$ purity), and the flow rate was $1.6 \mathrm{~mL} \cdot \mathrm{min}^{-1}$. The GC was equipped with a capillary column (Rtx-1, $30 \mathrm{~m} \times 0.25 \mathrm{~mm} \times 0.25 \mu \mathrm{m})$. During analysis, the column was initially maintained at a temperature of $100^{\circ} \mathrm{C}$, which was then increased at a rate of $20^{\circ} \mathrm{C} \cdot \mathrm{min}^{-1}$ to $210^{\circ} \mathrm{C}$, increased further at a rate of $3{ }^{\circ} \mathrm{C} \cdot \mathrm{min}^{-1}$ to $230^{\circ} \mathrm{C}$, and held for $5 \mathrm{~min}$. The temperature of the injector and detector was 
maintained at 250 and $280^{\circ} \mathrm{C}$, respectively. Splitting injection was taken and the injection volume was $1 \mu \mathrm{L}$. The recoveries of determination for lindane and $p, p^{\prime}$-DDE were $95.3 \%$ and $96.8 \%$, respectively.

\subsection{Data Analysis}

Linear and Freundlich models were used to fit the equilibrium sorption data. These models are expressed as follows:

$$
\begin{gathered}
\text { Linear model: } Q_{\mathrm{e}}=K_{\mathrm{H}} C_{\mathrm{e}} \\
\text { Freundlich model: } Q_{\mathrm{e}}=K_{\mathrm{F}} C \mathrm{e}^{\mathrm{n}}
\end{gathered}
$$

where $K_{\mathrm{H}}\left(\mathrm{L} \cdot \mathrm{g}^{-1}\right)$ and $K_{\mathrm{F}}\left[\left(\mu \mathrm{g} \cdot \mathrm{g}^{-1}\right) \cdot\left(\mu \mathrm{g} \cdot \mathrm{L}^{-1}\right)^{-\mathrm{n}}\right]$ are the linear and Freundlich model sorption coefficients, respectively. $Q_{\mathrm{e}}\left(\mu \mathrm{g} \cdot \mathrm{g}^{-1}\right)$ is the amount of sorbate sorbed onto solid materials; $C_{\mathrm{e}}\left(\mu \mathrm{g} \cdot \mathrm{L}^{-1}\right)$ is the sorbate equilibrium concentration; and $n$ is the Freundlich nonlinear coefficient.

The single-point distribution coefficient $K_{\mathrm{d}}\left(\mathrm{L} \cdot \mathrm{g}^{-1}\right)$ was used to compare the sorption capacities of sorbents at a certain equilibrium concentration. It was calculated by Equation (3):

$$
K_{\mathrm{d}}=\frac{Q_{\mathrm{e}}}{C_{\mathrm{e}}}
$$

The adjusted coefficient of determination $R^{2}$ adj was used to compare the performance of the two models and calculated by Equation (4):

$$
R_{\text {adj }}^{2}=1-\frac{\left(1-R^{2}\right)(N-1)}{N-M-1}
$$

where $N$ and $M$ are the numbers of experimental data points and parameters in the model, respectively.

The organic carbon standard partition coefficient $K_{\mathrm{OC}}\left[\left(\mu \mathrm{g} \cdot \mathrm{g}^{-1}\right) \cdot\left(\mu \mathrm{g} \cdot \mathrm{L}^{-1}\right)^{-\mathrm{n}}\right]$ reflects the sorption capacity of sediments on organic pollutants to some extent. It was calculated by Equation (5):

$$
K_{\mathrm{OC}}=\frac{K_{\mathrm{F}}}{f_{\mathrm{OC}}}
$$

where $K_{\mathrm{F}}$ is the Freundlich model sorption coefficients and $f_{\mathrm{OC}}$ is the quality percentage of TOC.

\section{Results}

The measured SSA and $f_{\mathrm{CM}}$ of SC, BC450, BC850, and AC are listed in Table 2. The order of SSA was AC $\left(525.1 \mathrm{~m}^{2} \cdot \mathrm{g}^{-1}\right)>\mathrm{BC} 850\left(79.6 \mathrm{~m}^{2} \cdot \mathrm{g}^{-1}\right)>\mathrm{BC} 450\left(26.5 \mathrm{~m}^{2} \cdot \mathrm{g}^{-1}\right)>\mathrm{SC}\left(21.4 \mathrm{~m}^{2} \cdot \mathrm{g}^{-1}\right)$. The order of $f_{\mathrm{CM}}$ was AC $(56.93 \%)>\mathrm{BC} 850(37.29 \%)>\mathrm{SC}(14.49 \%)>\mathrm{BC} 450(12.47 \%)$. The order of $f_{\mathrm{CM}}$ and SSA of the four CMs showed that $\mathrm{AC}$ and $\mathrm{BC} 850$ had better SSA and $f_{\mathrm{CM}}$ than SC and BC450, which could be related to their structures, given that $\mathrm{BC} 850$ was mainly consisted of an aromatic lamellar structure and had many irregular holes; compared with $\mathrm{BC} 850$, $\mathrm{AC}$ had smaller grain size, more pores, and less inorganic minerals [23]. While compared with AC and BC850, SC and BC450 had lower organic matter content and contained fewer pores [24]. The $f_{\mathrm{CM}}$ value of sediments was calculated by the $f_{\mathrm{CM}}$ value of SC shown in Table 2 . The value was only $0.17 \%$, because the sediments had a low content of organic matter which was mainly composed of nonliving organic matter such as humic substances [22].

Table 2. The specific surface area (SSA) and black carbon content $\left(f_{\mathrm{CM}}\right)$ of different kinds of carbonaceous materials.

\begin{tabular}{cccccc}
\hline & SD & SC & AC & BC450 & BC850 \\
\hline$f C M(\%)$ & $0.17^{\text {a }}$ & 14.49 & 56.93 & 12.47 & 37.29 \\
SSA $\left(\mathrm{m}^{2} \cdot \mathrm{g}^{-1}\right)$ & - & 21.4 & 525.1 & 26.5 & 79.6 \\
\hline
\end{tabular}

a The $f_{\mathrm{CM}}$ value of $\mathrm{SD}=$ (mass of SC $/$ mass of SD) $\times$ the $f_{\mathrm{CM}}$ value of SC. 


\subsection{Sorption Isotherms of Lindane and $p, p^{\prime}-D D E$ on the Sediments}

The parameters of the lindane and $p, p^{\prime}$-DDE sorption isotherms for the sediments fitted by the linear and Freundlich models are presented in Table S1. According to the values of $R^{2}$ adj, the linear model gave a better fit for the sorption isotherms of lindane and $p, p^{\prime}$-DDE on the sediments $\left(R^{2}\right.$ adj $>$ 0.983). The sorption isotherms are shown in Figure 1. The isotherms of lindane and $p, p^{\prime}$-DDE on the sediments appeared to be highly linear, suggesting that the linear partition could be involved in the sorption. Previous studies showed that the hydrophobic partition was the most important mechanism in the sorption of OCPs by natural solids [12,25].

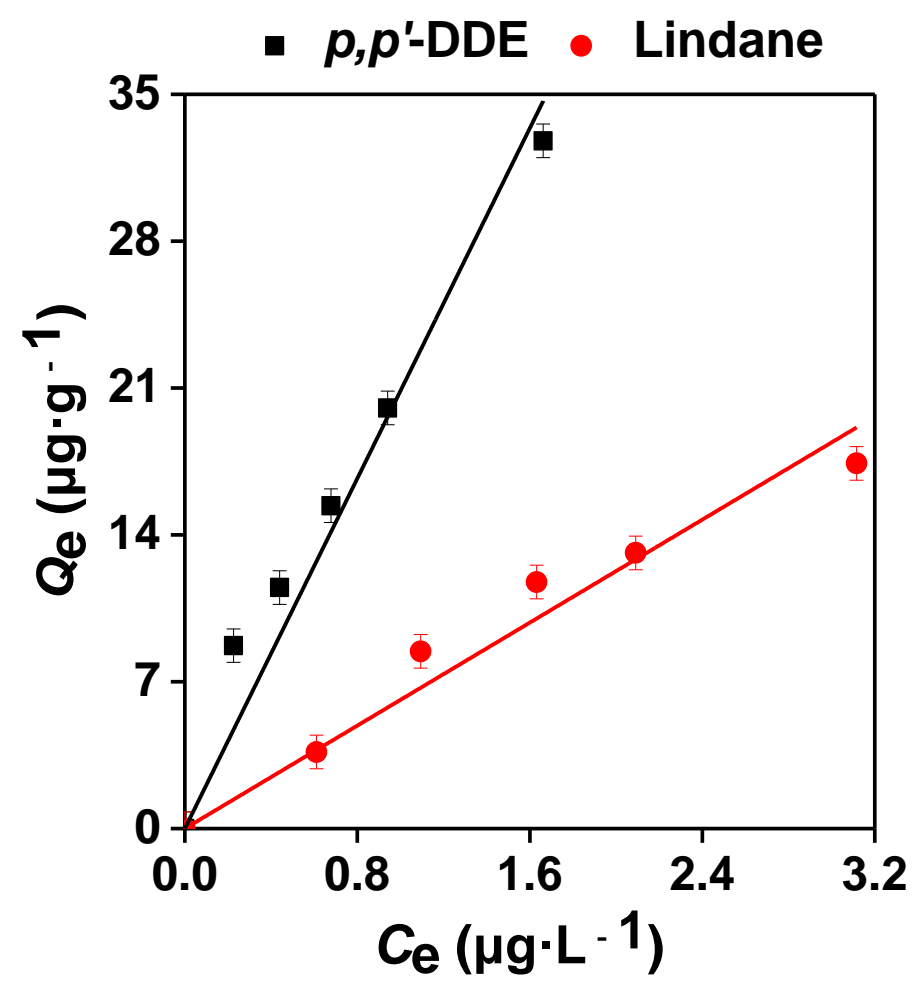

Figure 1. Sorption isotherms of lindane and $p, p^{\prime}$-DDE fitted by linear model on the sediments.

\subsection{Sorption Isotherms of Lindane and $p, p^{\prime}-D D E$ on $C M s$}

The parameters of the lindane and $p, p^{\prime}$-DDE sorption isotherms for SC, BC450, BC850, and AC, fitted by the linear and Freundlich models, are presented in Table S2. Both the lindane and $p, p^{\prime}$-DDE sorption isotherms for the four CMs were fitted better by the Freundlich model based on the $R^{2}$ adj values. The sorption isotherms are shown in Figure 2. The Freundlich nonlinear coefficient $n$ values for lindane sorbed by SC, BC450, BC850, and AC were 0.718, 0.818, 0.517, and 0.518, respectively, and the $n$ values for $p, p^{\prime}$-DDE were $0.478,0.632,0.385$, and 0.770 , respectively. The sorption of lindane and $p, p^{\prime}$-DDE on CMs appeared to be highly nonlinear. The order of $K_{\mathrm{d}}$ values for lindane sorption on the four CMs was AC $\left(1443.0 \mathrm{~L} \cdot \mathrm{g}^{-1}\right)>$ BC850 $\left(77.0 \mathrm{~L} \cdot \mathrm{g}^{-1}\right)>\mathrm{BC} 450\left(40.8 \mathrm{~L} \cdot \mathrm{g}^{-1}\right)>\mathrm{SC}\left(38.0 \mathrm{~L} \cdot \mathrm{g}^{-1}\right)$; the order of $p, p^{\prime}$-DDE was AC $\left(2926.2 \mathrm{~L} \cdot \mathrm{g}^{-1}\right)>$ BC850 $\left(565.2 \mathrm{~L} \cdot \mathrm{g}^{-1}\right)>\mathrm{SC}\left(318.1 \mathrm{~L} \cdot \mathrm{g}^{-1}\right)>\mathrm{BC} 450\left(122.3 \mathrm{~L} \cdot \mathrm{g}^{-1}\right)$.

\subsection{Effects of SC with Different Contents on the Sorption of Lindane and $p, p^{\prime}-D D E$ by the Sediments}

The sorption isotherm parameters of lindane and $p, p^{\prime}$-DDE on the sediments added by SC with different contents fitted by the linear and Freundlich models are presented in Table S3. Both the lindane and $p, p^{\prime}$-DDE sorption isotherms were fitted better by the Freundlich model based on the $R^{2}$ adj values. The sorption isotherms are shown in Figure 3. The Freundlich nonlinear coefficient $n$ values for lindane sorbed on the sediments with $0.5 \%$ SC, $1.5 \%$ SC, $3.0 \%$ SC, $5.0 \%$ SC, and $9.0 \%$ SC 
were $0.778,0.889,0.785,0.709,0.585$, and 0.492 , respectively; and the $n$ values for $p, p^{\prime}$-DDE were 0.763 , $0.907,0.734,0.743,0.558$, and 0.476 , respectively. The $K_{d}$ values for lindane sorption on the sediments with different contents of SC increased in the following order: sediments $\left(6.6 \mathrm{~L} \cdot \mathrm{g}^{-1}\right)<$ sediments with $0.5 \%$ SC $\left(11.9 \mathrm{~L} \cdot \mathrm{g}^{-1}\right)<$ sediments with $1.5 \%$ SC $\left(14.4 \mathrm{~L} \cdot \mathrm{g}^{-1}\right)<$ sediments with $3.0 \%$ SC $\left(23.5 \mathrm{~L} \cdot \mathrm{g}^{-1}\right)<$ sediments with $5.0 \%$ SC $\left(33.1 \mathrm{~L} \cdot \mathrm{g}^{-1}\right)<$ sediments with $9.0 \% \mathrm{SC}\left(49.4 \mathrm{~L} \cdot \mathrm{g}^{-1}\right)$. The order of $p, p^{\prime}$-DDE was sediments $\left(25.7 \mathrm{~L} \cdot \mathrm{g}^{-1}\right)<$ sediments with $0.5 \% \mathrm{SC}\left(49.7 \mathrm{~L} \cdot \mathrm{g}^{-1}\right)<$ sediments with $1.5 \% \mathrm{SC}\left(65.0 \mathrm{~L} \cdot \mathrm{g}^{-1}\right)<$ sediments with $3.0 \%$ SC $\left(92.7 \mathrm{~L} \cdot \mathrm{g}^{-1}\right)<$ sediments with $5.0 \%$ SC $\left(145.8 \mathrm{~L} \cdot \mathrm{g}^{-1}\right)<$ sediments with $9.0 \%$ SC $\left(241.4 \mathrm{~L} \cdot \mathrm{g}^{-1}\right)$, respectively. The $K_{\mathrm{d}}$ values increased with the increase of SC contents in the sediments.

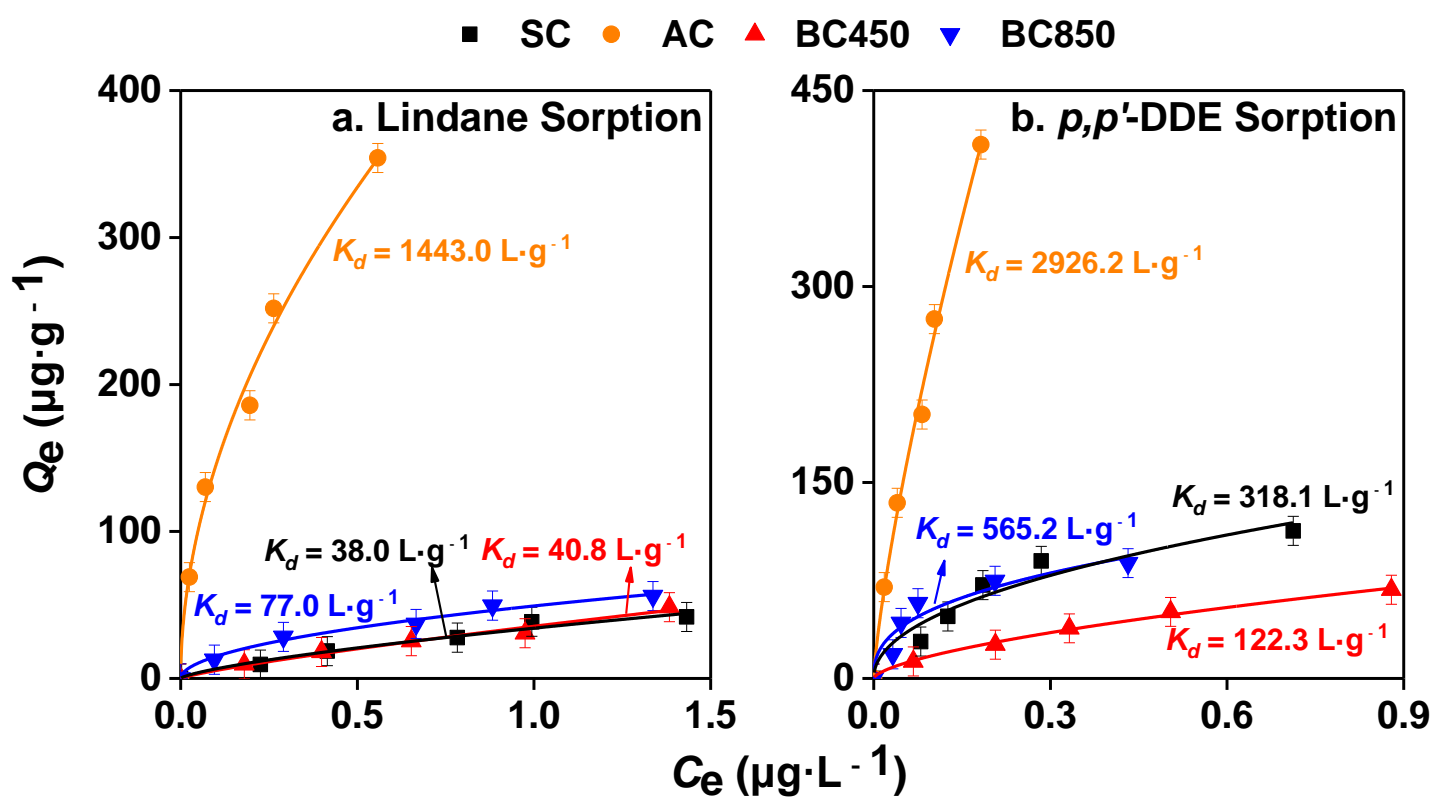

Figure 2. Sorption isotherms of lindane (a) and $p, p^{\prime}$-DDE (b) fitted by Freundlich model on different kinds of CMs.

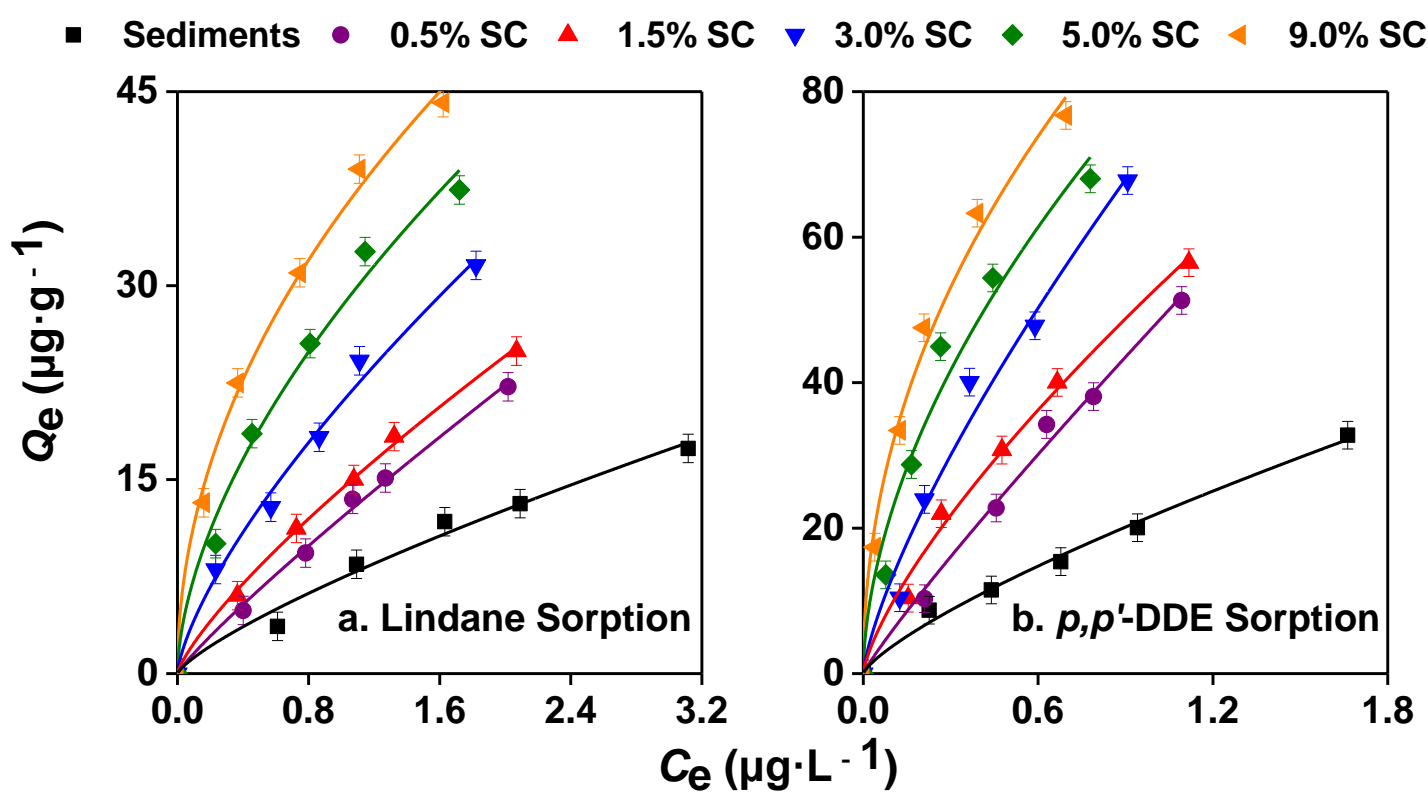

Figure 3. Sorption isotherms of lindane (a) and $p, p^{\prime}$-DDE (b) fitted by Freundlich model on the sediments with different contents of SC. 


\section{Discussion}

The sorption characteristics of CMs were closely related to their physicochemical properties. According to the $n$ values, the sorption isotherms of BC850 and AC almost had good nonlinearity, because they had more micro-pores and higher $\mathrm{BC}$ content, but the sorption isotherms of $p, p^{\prime}$-DDE on $\mathrm{AC}$ appeared to be slightly linear, suggesting that the linear partition was involved in the sorption of $p, p^{\prime}$-DDE on AC [26]. Comparing the $n$ values of SC with BC450, the nonlinearity of lindane and $p, p^{\prime}$-DDE sorption isotherms on SC was much stronger than that of BC450. Pore-filling was found to account for a significant proportion of the nonlinearity sorption process of HCHs and DDTs by CMs [27-31]. As such, the explanation for why the sorption of SC had a better nonlinearity could be related to its porosity, because $\mathrm{BC} 450$ had a very low level of porosity due to its incomplete pyrolysis, while SC contained more microporous structures [24,32]. The porosity could be an important factor affecting the nonlinearity of CMs.

The $K_{\mathrm{d}}$ values showed that the sorption capacity of lindane and $p, p^{\prime}$-DDE by AC and BC850 was 1.8-38.0 times larger than that of SC. Comparing the sorption capacity of BC450 and SC, they were similar, though the SC sorption was slightly superior to that of $\mathrm{BC} 450$. The sorption capacities of CMs were closely related to their content of BC [33,34]. Previous studies showed that BC had a strong sorption capacity and could play a leading role in the entire sorption of natural solids despite its content being very low; when the proportion of BC in TOC was only $23 \%$, the contribution rate to the entire sorption could reach $52 \%$ [35-37]. Furthermore, the correlation analysis between $f_{\mathrm{CM}}$ and $K_{\mathrm{d}}$ in this study showed that the two had good correlation $(r>0.85)$. Thus, it was speculated that the difference of $f_{\mathrm{CM}}$ could be the reason why the sorption capacity of SC was stronger than that of $\mathrm{BC} 450$. This shows that $f_{\mathrm{CM}}$ is an important factor affecting the sorption capacity of CMs.

The sorption capacity of BC850 and AC was at least 11-21 times higher than that of natural sediments, while SC and BC450 were only 4-11 times higher than that of natural sediments. Adding a small amount of $\mathrm{BC} 850$ or $\mathrm{AC}$ to natural sediments could significantly increase the proportion of $\mathrm{BC}$ in TOC; by contrast, adding SC and BC450 could gradually increase said proportion of BC in TOC, meaning that they were more suitable to investigate the effects of $\mathrm{CMs}$ content on the sorption of lindane and $p, p^{\prime}$-DDE by the sediments. Comparing SC with BC450, SC had higher $f_{\mathrm{CM}}$ and more pores, therefore, it was chosen to investigate the effects of CMs on the sorption of lindane and $p, p^{\prime}$-DDE by the sediments.

As the contents of SC increased in the sediments, the $n$ values of lindane sorption on the latter decreased from 0.889 to 0.492 , and the $n$ values of $p, p^{\prime}$-DDE decreased from 0.907 to 0.476 , suggesting that the nonlinearity of the sorption became stronger. The same situation was observed in previous studies [35,36], indicating that the content of SC was an important factor affecting the nonlinearity of the sorption of lindane and $p, p^{\prime}$-DDE by the sediments. By comparing the $K_{\mathrm{d}}$ values of the sediments with different contents of SC, the sorption capacity of lindane sorption on the sediments with $0.5-9.0 \%$ $\mathrm{SC}$ was 1.8-7.5 times larger than that of natural sediments, and the sorption capacity of $p, p^{\prime}$-DDE sorption on the sediments with $0.5-9 \%$ SC was 1.9-9.4 times larger than that of natural sediments, respectively. The correlation analysis between $f_{\mathrm{CM}}$ and $K_{\mathrm{d}}$ showed that the two had good correlation $(r>0.99)$, and combined what was shown in Figure 3, the conclusion could be drawn that the sorption capacity of sediments was closely related to the content of SC [36-39]. The values of $K_{\mathrm{F}}$ reflected the sorption capacity of natural solids to some extent [40], when the proportion of CMs in TOC increased from 0 to $60 \%$, the $K_{\mathrm{F}}$ values of lindane sorption increased from 7.38 to 35.69 , increased by 3.8 times, and the $K_{\mathrm{F}}$ values of $p, p^{\prime}$-DDE sorption increased from 21.83 to 94.19 , increased by 3.3 times, which also confirmed the importance of SC content in the sorption of lindane and $p, p^{\prime}$-DDE by the sediments.

The contribution of SC to the sorption of the sediments was calculated as follows: the difference between the amount of pesticides sorbed by the sediments with different contents of SC and natural sediments was taken as the amount of pesticides sorbed by SC; the ratio of the amount of pesticide sorbed by SC and the amount of pesticide sorbed by the sediments with different contents of SC was recorded as the contribution of SC to the sorption of lindane and $p, p^{\prime}$-DDE by the sediments. Figure 4 
shows the relationship between the ratio of $\mathrm{CMs}$ and TOC $\left(f_{\mathrm{CM}} / f_{\mathrm{OC}}\right)$ and the sorption contribution rate of SC. When the ratios of $f_{\mathrm{CM}} / f_{\mathrm{OC}}$ were $0.10,0.22,0.35,0.46$, and 0.60 , the contribution rates of SC to the sorption of lindane were $16.4 \%, 28.9 \%, 43.1 \%, 57.1 \%$, and $64.7 \%$, respectively; the contribution rates of SC to the sorption of $p, p^{\prime}$-DDE were $40.7 \%, 41.1 \%, 50.0 \%, 55.3 \%$, and $61.7 \%$, respectively, which was similar to the results reported by Xia et al. and Liu et al. [35,41], indicating that the ratio of $f_{\mathrm{CM}} / f_{\mathrm{OC}}$ was an important factor affecting the sorption of lindane and $p, p^{\prime}$-DDE by the sediments.

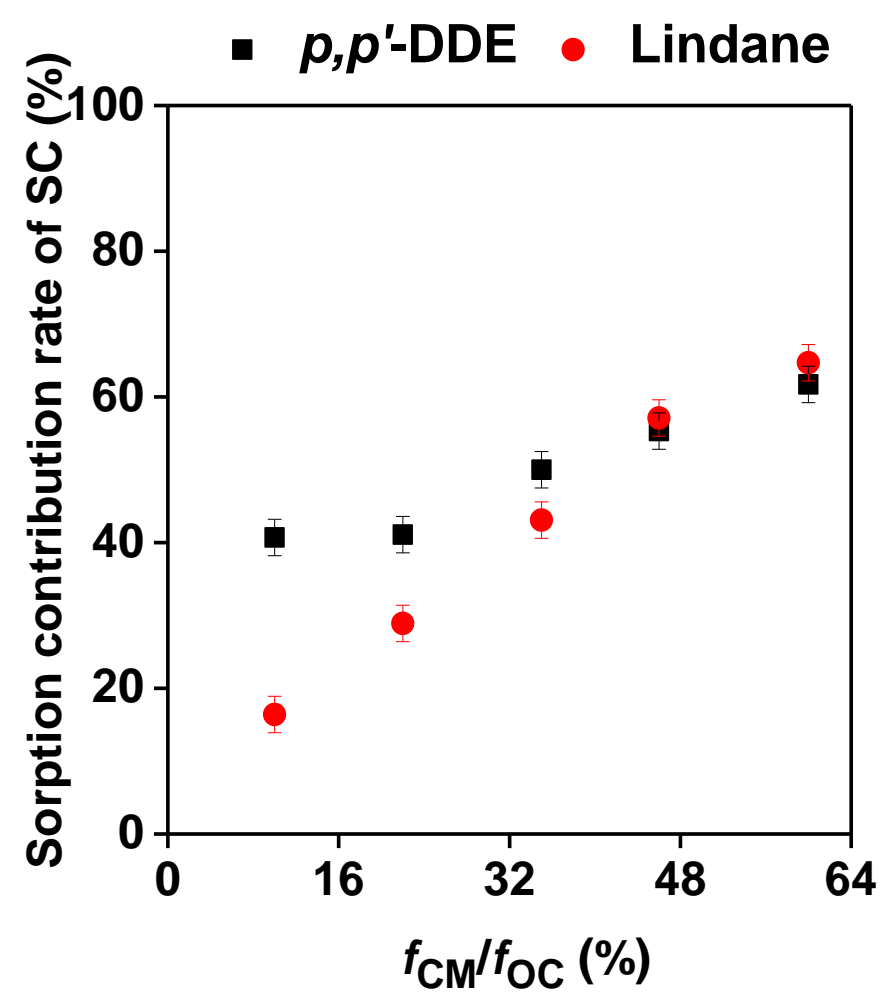

Figure 4. The relationship between the ratio of $f_{\mathrm{CM}} / f_{\mathrm{OC}}$ and sorption contribution rate of SC.

The organic carbon standardized partition coefficient $\left(K_{\mathrm{OC}}\right)$ reflects the sorption capacity of the sediments for organic pollutants [12]. The values of $K_{\mathrm{OC}}$ and the ratios of $f_{\mathrm{CM}} / f_{\mathrm{OC}}$ are listed in Table 3. When the ratio of $f_{\mathrm{CM}} / f_{\mathrm{OC}}$ in the sediments was low, as in $0.10-0.22$, the change of $f_{\mathrm{CM}}$ had little effect on the value of $K_{\mathrm{OC}}$, and the contribution rate of SC was below $50 \%$. At this time, CMs played a minor role in the sorption of lindane and $p, p^{\prime}$-DDE by the sediments; when $f_{\mathrm{CM}} / f_{\mathrm{OC}}$ was higher, as in $0.35-0.60$, CMs gradually played a leading role in the sorption, the contribution rate of SC even went up to $64.7 \%$, and the higher the $f_{\mathrm{CM}}$, the greater the effect on the values of $K_{\mathrm{OC}}$. This indicates that $f_{\mathrm{CM}} / f_{\mathrm{OC}}$ could be a principal parameter for assessing the sorption capacity of sediments and CMs for the hydrophobic OCPs.

Table 3. The values of $f_{\mathrm{CM}}, f_{\mathrm{OC}}, f_{\mathrm{CM}} / f_{\mathrm{OC}}$, and $K_{\mathrm{OC}}$ of the sediments with different contents of SC.

\begin{tabular}{|c|c|c|c|c|c|c|}
\hline & Sediments & $0.5 \%$ SC & $1.5 \% \mathrm{SC}$ & $3.0 \% \mathrm{SC}$ & $5.0 \% \mathrm{SC}$ & $9.0 \% \mathrm{SC}$ \\
\hline$f_{\mathrm{CM}}(\%)$ & 0.17 & 0.67 & 1.67 & 3.17 & 5.17 & 9.17 \\
\hline$f_{\mathrm{OC}}(\%)$ & 6.16 & 6.66 & 7.66 & 9.16 & 11.16 & 15.16 \\
\hline$f_{\mathrm{CM}} / f_{\mathrm{OC}}$ & 0.03 & 0.10 & 0.22 & 0.35 & 0.46 & 0.60 \\
\hline $\begin{array}{c}K_{\mathrm{OC}}-\text { lindane } \\
{\left[\left(\mu \mathrm{g} \cdot \mathrm{g}^{-1}\right) \cdot\left(\mu \mathrm{g} \cdot \mathrm{L}^{-1}\right)^{-\mathrm{n}}\right]}\end{array}$ & 119.82 & 180.81 & 186.17 & 228.41 & 253.94 & 235.44 \\
\hline $\begin{array}{c}K_{\mathrm{OC}}-p, p^{\prime}-\mathrm{DDE} \\
{\left[\left(\mu \mathrm{g} \cdot \mathrm{g}^{-1}\right) \cdot\left(\mu \mathrm{g} \cdot \mathrm{L}^{-1}\right)^{-\mathrm{n}}\right]}\end{array}$ & 346.23 & 718.90 & 688.12 & 801.81 & 731.11 & 621.31 \\
\hline
\end{tabular}




\section{Conclusions}

In this study, the factors affecting the sorption of lindane and $p, p^{\prime}$-DDE by CMs were explored by comparing the four CMs including SC, BC450, BC850, and AC. The results indicated that when the ratio of $f_{\mathrm{CM}} / f_{\mathrm{OC}}$ was greater than 0.35 , CMs played a leading role in the sorption of lindane and $p, p^{\prime}-D D E$ on the sediments. The sorption contribution rate of $C M$ s could reach up to $64.7 \%$. When the ratio of $f_{\mathrm{CM}} / f_{\mathrm{OC}}$ was less than $0.10, \mathrm{BC}$ played a minor role in the sorption. The nonlinearity of sorption isotherms was strengthened with the increasing $f_{\mathrm{CM}}$ and porosity. Our findings show that the porosity of CMs was an important factor affecting the nonlinearity of sorption isotherms and $f_{\mathrm{CM}} / f_{\mathrm{OC}}$ is a principal parameter for assessing the sorption capacity of sediments and CMs for the hydrophobic OCPs.

Supplementary Materials: The following are available online at http://www.mdpi.com/2076-3417/9/9/1722/s1, Table S1. Isotherm parameters for lindane and $p, p^{\prime}$-DDE sorption by the sediments; Table S2. Isotherm parameters for lindane and $p, p^{\prime}$-DDE sorption by different kinds of CMs; Table S3. Isotherm parameters for lindane and $p, p^{\prime}$-DDE sorption by the sediments with different contents of SC.

Author Contributions: Conceptualization: Z.G.; data curation: L.Z.; formal analysis: L.Z.; funding acquisition: Z.G. and X.H.; investigation: T.C. and L.W.; methodology, Z.G.; software: T.C.; supervision: D.D. and X.H.; writing —original draft: Z.G. and T.C.; writing—review and editing: X.W.

Funding: This study was supported by the National Natural Science Foundation of China (no. 21307041 and 21277056), and the 111 Project (no. B16020).

Conflicts of Interest: The authors declare no conflict of interest.

\section{References}

1. Parween, M.; Ramanathan, A.L.; Khillare, P.S.; Raju, N.J. Persistence, variance and toxic levels of organochlorine pesticides in fluvial sediments and the role of black carbon in their retention. Environ. Sci. Pollut. Res. 2014, 21, 6525-6546. [CrossRef]

2. Meng, J.; Hong, S.J.; Wang, T.Y.; Li, Q.F.; Yoon, S.J.; Lu, Y.L.; GiesyJohn, J.P.; Khim, J.S. Traditional and new POPs in environments along the Bohai and Yellow Seas: An overview of China and South Korea. Chemosphere 2017, 169, 503-515. [CrossRef] [PubMed]

3. Abhilash, P.C.; Jamil, S.; Singh, V.; Singh, A.; Singh, N.; Srivastava, S.C. Occurrence and distribution of hexachlorocyclohexane isomers in vegetation samples from a contaminated area. Chemosphere. 2008, 72, 79-86. [CrossRef] [PubMed]

4. Nizzetto, L.; Macleod, M.; Borga, K.; Cabrerizo, A.; Dachs, J.; Di Guardo, A.; Ghirardello, D.; Hansen, K.M.; Jarvis, A.; Lindroth, A.; et al. Past, present, and future controls on levels of persistent organic pollutants in the global environment. Environ. Sci. Technol. 2010, 44, 6526-6531. [CrossRef] [PubMed]

5. Lin, T.; Nizzetto, L.; Guo, Z.G.; Li, Y.Y.; Li, J.; Zhang, G. DDTs and HCHs in sediment cores from the coastal East China Sea. Sci. Total Environ. 2016, 539, 388-394. [CrossRef]

6. Dominguez, C.M.; Oturan, N.; Romero, A.; Santos, A.; Oturan, M.A. Lindane degradation by electrooxidation process: Effect of electrode materials on oxidation and mineralization kinetics. Water Res. 2018, 135, 220-230. [CrossRef] [PubMed]

7. Khan, S.; He, X.X.; Khan, J.A.; Khan, H.M.; Boccelli, D.L.; Dionysiou, D.D. Kinetics and mechanism of sulfate radical-and hydroxyl radical-induced degradation of highly chlorinated pesticide lindane in UV/peroxymonosulfate system. Chem. Eng. J. 2017, 318, 135-142. [CrossRef]

8. Tavares, R.S.; Amaral, S.; Paiva, C.; Baptista, M.; Ramalho-Santos, J. In vitro exposure to the organochlorine $p, p^{\prime}$-DDE affects functional human sperm parameters. Chemosphere 2015, 120, 443-446. [CrossRef] [PubMed]

9. Jurgens, M.D.; Crosse, J.; Hamilton, P.B.; Johnson, A.C.; Jones, K.C. The long shadow of our chemical past High DDT concentrations in fish near a former agrochemicals factory in England. Chemosphere 2016, 162, 333-344. [CrossRef] [PubMed]

10. Jayasinghe, S.; Lind, L.; Salihovic, S.; Larsson, A.; Lind, P.M. High serum levels of $p$, p'-DDE are associated with an accelerated decline in GFR during 10years follow-up. Sci. Total Environ. 2018, 644, 371-374. [CrossRef] [PubMed] 
11. Zhu, X.J.; Dsikowitzky, L.; Kucher, S.; Ricking, M.; Schwarzbauer, J. Formation and fate of point-source nonextractable DDT-related compounds on their environmental aquatic-terrestrial pathway. Environ. Sci. Technol. 2019, 53, 1305-1314. [CrossRef]

12. Guo, Z.Y.; Dong, D.M.; Hua, X.Y.; Zhang, L.W.; Zhu, S.J.; Lan, X.H.; Liang, D.P. Cr and As decrease lindane sorption on river solids. Environ. Chem. Lett. 2015, 13, 111-116. [CrossRef]

13. Kohusova, K.; Havel, L.; Vlasak, P.; Tonika, J. A long-term survey of heavy metals and specific organic compounds in biofilms, sediments, and surface water in a heavily affected river in the Czech Republic. Environ. Monit. Assess. 2011, 174, 555-572. [CrossRef] [PubMed]

14. Guo, Z.Y.; Hua, X.Y.; Lan, X.H.; Sun, Y.Y.; Dong, D.M. Evidence for a mutual effect of biofilms, suspended particles and sediments on DDT sorption. Environ. Chem. Lett. 2012, 10,407-411. [CrossRef]

15. Oliveira, A.H.B.; Cavalcante, R.M.; Duavi, W.C.; Fernandes, G.M.; Nascimento, R.F.; Queiroz, M.E.L.R.; Mendonça, K.V. The legacy of organochlorine pesticide usage in a tropical semi-arid region (Jaguaribe River, Ceará, Brazil): Implications of the influence of sediment parameters on occurrence, distribution and fate. Sci. Total Environ. 2016, 542, 254-263. [CrossRef] [PubMed]

16. Ogbeide, O.; Chukwuka, A.; Tongo, I.; Ezemonye, L. Relationship between geosorbent properties and field-based partition coefficients for pesticides in surface water and sediments of selected agrarian catchments: Implications for risk assessment. J. Environ. Manage. 2018, 217, 23-27. [CrossRef]

17. Zhang, G.X.; Zhang, Q.; Sun, K.; Liu, X.T.; Zheng, W.J.; Zhao, Y. Sorption of simazine to corn straw biochars prepared at different pyrolytic temperatures. Environ. Pollut. 2011, 159, 2594-2601. [CrossRef] [PubMed]

18. Kah, M.; Sigmund, G.; Xiao, F.; Hofmann, T. Sorption of ionizable and ionic organic compounds to biochar, activated carbon and other carbonaceous materials. Water Res. 2017, 124, 673-692. [CrossRef] [PubMed]

19. Ahmad, M.; Rajapaksha, A.U.; Lim, J.E.; Zhang, M.; Bolan, N.; Mohan, D.; Vithanage, M.; Lee, S.S.; Ok, Y.S. Biochar as a sorbent for contaminant management in soil and water: A review. Chemosphere. 2014, 99, 19-33. [CrossRef]

20. Lim, B.; Cachier, H. Determination of black carbon by chemical oxidation and thermal treatment in recent marine and lake sediment and Cretaceous-Tertiary clays. Chem. Geol. 1996, 131, 143-154. [CrossRef]

21. Hsieh, Y.P.; Bugna, G.C. Analysis of black carbon in sediments and soils using multi-element scanning thermal analysis (MESTA). Org. Geochem. 2008, 39, 1562-1571. [CrossRef]

22. Dong, D.M.; Li, L.F.; Zhang, L.W.; Hua, X.Y.; Guo, Z.Y. Effects of lead, cadmium, chromium, and arsenic on the sorption of lindane and norfloxacin by river biofilms, particles, and sediments. Environl. Sci. Pollut. Res. 2018, 25, 4632-4642. [CrossRef]

23. Ahmed, M.B.; Zhou, J.L.; Ngo, H.H.; Guo, W.S. Adsorptive removal of antibiotics from water and wastewater: Progress and challenges. Sci. Total Environ. 2017, 532, 112-126. [CrossRef]

24. Lian, F.; Xing, B.S. Black carbon (biochar) in water/soil environments: Molecular structure, sorption, stability, and potential risk. Environ. Sci. Technol. 2017, 51, 13517-13532. [CrossRef]

25. Zhang, L.W.; Dong, D.M.; Xie, Y.J.; Guo, Z.Y.; Hua, X.Y. Coexisting sediments and suspended particles change the sorption of lindane and ciprofloxacin in waters. Environ. Chem. Lett. 2018, 16, 1043-1048. [CrossRef]

26. Cornelissen, G.; Gustafsso, O.; Bucheli, T.D.; Jonker, M.T.O.; Koelmans, A.A.; Van Noort, P.C.M. Extensive sorption of organic compounds to black carbon, coal, and kerogen in sediments and soils: Mechanisms and consequences for distribution, bioaccumulation, and biodegradation. Environ. Sci. Technol. 2005, 39, 6881-6895. [CrossRef]

27. Braida, W.J.; Pignatello, J.J.; Lu, Y.F.; Ravikovitch, P.I.; Neimark, A.V.; Xing, B.S. Sorption hysteresis of benzene in charcoal particles. Environ. Sci. Technol. 2003, 37, 409-417. [CrossRef]

28. Pignatello, J.J.; Kwon, S.; Lu, Y.F. Effect of natural organic substances on the surface and adsorptive properties of environmental black carbon (char): Attenuation of surface activity by humic and fulvic acids. Environ. Sci. Technol. 2006, 40, 7757-7763. [CrossRef]

29. Chen, Z.M.; Chen, B.L.; Zhou, D.D.; Chen, W.Y. Bisolute sorption and thermodynamic behavior of organic pollutants to biomass-derived biochars at two pyrolytic temperatures. Environ. Sci. Technol. 2012, 46, 12476-12483. [CrossRef]

30. Lian, F.; Chang, C.; Du, Y.; Zhu, L.; Xing, B.; Liu, C. Adsorptive removal of hydrophobic organic compounds by carbonaceous adsorbents: A comparative study of waste-polymer-based, coal-based activated carbon, and carbon nanotubes. J. Environ. Sci. 2012, 24, 1549-1558. [CrossRef] 
31. Lorenc-Grabowska, E.; Gryglewicz, G.; Diez, M.A. Kinetics and equilibrium study of phenol adsorption on nitrogen-enriched activated carbons. Fuel. 2013, 114, 235-243. [CrossRef]

32. Yu, X.Y.; Ying, G.G.; Kookana, R.S. Sorption and desorption behaviors of diuron in soils amended with charcoal. J. Agric. Food Chem. 2006, 54, 8545-8550. [CrossRef]

33. Zhao, L.; Cao, X.D.; Masek, O.; Zimmerman, A. Heterogeneity of biochar properties as a function of feedstock sources and production temperatures. J. Hazard. Mater. 2013, 256, 1-9. [CrossRef]

34. Kupryianchyk, D.; Hale, S.; Zimmerman, A.R.; Harvey, O.; Rutherford, D.; Abiven, S.; Knicker, H.; Schmidt, H.P.; Rumpel, C.; Cornelissen, G. Sorption of hydrophobic organic compounds to a diverse suite of carbonaceous materials with emphasis on biochar. Chemosphere. 2016, 144, 879-887. [CrossRef]

35. Xia, X.H.; Dai, Z.N.; Li, Y.R. The role of black carbon in the sorption and desorption of phenanthrene on river sediments. Environ. Earth Sci. 2011, 64, 2287-2294. [CrossRef]

36. Ali, U.; Bajwa, A.; Chaudhry, M.J.I.; Mahmood, A.; Syed, J.H.; Li, J.; Zhang, G.; Jones, K.C.; Malik, R.N. Significance of black carbon in the sediment-water partitioning of organochlorine pesticides (OCPs) in the Indus River, Pakistan. Ecotox. Environ. Safe. 2016, 126, 177-185. [CrossRef]

37. Bajwa, A.; Ali, U.; Mahmood, A.; Chaudhry, M.J.I.; Syed, J.H.; Li, J.; Zhang, G.; Jones, K.C.; Malik, R.N. Organochlorine pesticides (OCPs) in the Indus River catchment area, Pakistan: Status, soil-air exchange and black carbon mediated distribution. Chemosphere 2016, 152, 292-300. [CrossRef]

38. Jin, L.X.; He, M.C.; Zhang, J.H.; Xia, X.H. Norfloxacin sorption to different fractions in sediments from typical water systems in China. Soil Sediment Contam. 2011, 20, 564-580. [CrossRef]

39. Zhang, L.; Dickhut, R.; DeMaster, D.; Pohl, K.; Lohmann, R. Organochlorine pollutants in Western Antarctic Peninsula sediments and benthic deposit feeders. Environ. Sci. Technol. 2013, 47, 5643-5651. [CrossRef]

40. Kannan, N.; Sundaram, M.M. Kinetics and mechanism of removal of methylene blue by adsorption on various carbons—a comparative study. Dyes Pigm. 2001, 51, 25-40. [CrossRef]

41. Liu, J.Q.; Zhang, Y.B.; Chen, H.; Zhao, Y.Z.; Quan, X. Contribution of black carbon to nonlinearity of sorption and desorption of acetochlor on sediment. Front. Environ. Sci. Eng. China. 2009, 3, 69-74. [CrossRef]

(C) 2019 by the authors. Licensee MDPI, Basel, Switzerland. This article is an open access article distributed under the terms and conditions of the Creative Commons Attribution (CC BY) license (http://creativecommons.org/licenses/by/4.0/). 